\title{
Change and Continuity in Translation. Renewing Communication in a Globalised World
}

Vertimo kaita ir tęstinumas. Komunikacijos atnaujinimas globalizuotame pasaulyje

\section{TRANSLATION / VERTIMAS}

\section{Yves Gambier}

University of Turku, Finland

\author{
Crossef http://dx.doi.org/10.5755/j01.sal.1.37.27760
}

At first sight, technology is transforming rapidly the workflow in translation. Like in many other fields, digital technology impacts translators' daily life. Technology is so omnipresent that we are hardly capable of measuring the consequences it had, the metamorphosis it has induced. On the other hand, we are also so fascinated by all the technical devices and platforms we can use that we tend to forget or undermine the past and how technology and media have always played a role in the evolution of our cultures. Looking back in history, we can realise that some current practices in translation, considered as new, are not really so new.

The use of multimodal "texts" we are referring to everyday is not without analogy with the production and the reading of "texts" in the past. Perhaps the transition from a logocentric to an intersemiotic and intermedial culture puts an end to a limited period of time in history, dominated by printing. But closing the "Gutenberg parenthesis" does not imply coming across the same artefacts again as before the 15th century.

Based on the existing literature, our paper questions the borders between some translation practice, media, disciplines, through an historical perspective.

KEYWORDS: codex, equivalence, media history of translation, mediology, multimodal text, printing, reading, technopoly, transdisciplinarity.

The currently ongoing coronavirus pandemic has clearly shown that although there were differences in lockdown between societies and borders were closed, we remained connected: not only through the Net and mobile phones but also through the virus. However, "contact" should neither be confused with "tweet", "like" and "share", nor with contamination (Turkle, 2011). Across time, technology has been the topic of ecstatic, even euphoric, discourse, especially since the $19^{\text {th }}$ century, for instance, about electricity or trains. In the last decades, Information and Communication Technology (ICT) has become so omnipresent, so invisible (except when it breaks down or when social media disseminates awful fake news, incites racial hatred or violent sexism, etc.), that we tend to ignore the impact it has had, and still has, on our way of thinking, behaving and managing things, and our knowledge.

Technology and Culture ktu

Research Journal Studies about Languages No. $37 / 2020$, pp. 5-19 ISSN 1648-2824 (print) ISSN 2029-7203 (online) Doi.org/10.5755/j01.sal.37.1.27760 
Let us first recall the rapid changes of ICT digital technology, with some hardware, software and platforms:

- 1975: Microsoft; 1983: Microsoft Word; 1989: Windows

- 1980s: Minitel

- January 1984: $1^{\text {st }}$ Maclntosh (Apple)

- 1989: World Wide Web $\rightarrow$ August 1991: released to the public

- 1995: Yahoo (star of the time!). End of 1995: USB

- May 1998: MP3 (1st standard in digital music)

- September 1998: Google; 1999: Alibaba (China); 2000: Baidu (China)

- 2000: Millennium bug + 2001: Internet bubble/dot-com bubble

- 2004: Facebook; 2005: You tube; 2006: Vkontakt (Russia); 2009: WhatsApp;

- 2010: Instagram; 2011: WeChat (China); Snapchat

When we refer to a "revolution" (nothing will be the same as before), we mainly refer to technology. We have learnt that political revolutions are reversible: after the Soviets, a country can return to tsarism, but after the pocket calculator, we will never return to the abacus, after electromagnetic detection, we will never return to the water-divining rod. Firms, universities and public opinion subscribe to the myth of permanent technological change, through the concept of innovation (disruptive innovation, of course). But what are we talking about? What is that cult that is organised by start-ups, fairs such as Viva Technology in Paris, the Consumer Electronics Show / CES in Las Vegas, and other hackathons (hacking marathons), where computer programmers, software freaks, interface designers, etc., collaborate as if technology was taking place outside any socio-economic context. The hubris of innovation is the substitute for "progress" thanks to science and rationality, which seduced a certain elite in the $19^{\text {th }}$ century. In fairs, institutions and services, innovation is always top-down and without history (Goggin et al., 2017; Brügger et al., 2018, 2019). What is missing in this new promise of a brighter future is culture, i.e., ways we can integrate technology into our behaviour, ways we can give values to technology, ways we can think of the relevance and efficiency of the new technology. Yet technology and culture are considered apart': we have a Ministry of Science and Technology, a Ministry of Education and Culture; we have a Faculty of Science and Technology, a Faculty of Humanities. This opposition has very distant roots since, for instance, ancient Greek philosophy was formed by marginalising the question of teckné, i.e., production, material making, efficient action, as if technology was not constituent of the philosophical truth. The coronavirus pandemic has revealed the extent to which we could not think of health only in terms of technical devices but we had also to take into account individual and collective behaviours, emotions and values, as if suddenly we have realised we are not "homme-machine", automatons, derived from the "animal-machine", the mechanical philosophy (after Descartes). Our fast and so-called advanced society has been brought to its knees by a virus - one of the most ambiguous living beings (between the chemical life of organic matter and biological life): Earth can eliminate us with one of the smallest creatures.

The objective here is not to criticise, reject or discuss artificial intelligence, virtual reality, augmented reality, connected objects, big data, robots, Big Brother, Silicolonisation, digital

\footnotetext{
1 The ploughshare was invented in China (3rd BC) but imported to Europe only in the 17th century where the ard (a simple light plough) was still dominant. The introduction of the ploughshare boosted farm production in parallel with the beginning of the Enlightenment. Any society can lack "obvious" techniques, e.g., there is a gap of 2000 years between the use of the wheel in Mesopotamia and in Egypt.
} 
democracy, digital business, e-commerce, etc. The objective here is not to fall into the trap of "solutionism" (the belief that technology can solve all our problems, from pollution to crime, from corruption to safety, from obesity to social relationship) and "webcentrism" (the belief that the technology disruption of today, with its predictive algorithms, is somehow unique in history) (Morozov, 2013). The objective here is how to think about technology and culture if we want to progress beyond the illusions of technology's omnipotence.

A fair number of writers and scholars have not only been investigating how our online world supports diverse voices and works of lasting value but also how it amplifies real-world iniquities and divides (Taylor, 2014). Very often the argument is Manichean, binary: the technoptimists (cheerleaders of progress at any cost) opposed to the techno-sceptics (prophets of doom) - the two camps framing questions in such a way that technology remains central, adopting the language and vision of Silicon Valley executives, and sidestepping the social and cultural structures in which we are embedded and our technologies are shaped (Leonhard, 2016).

I will refer here to two frameworks: technopoly and mediology. "Technopoly" is a concept developed by the American media theorist Neil Postman (1931-2003) in a book published in 1992 when the Arpanet was the only packet-network (operational from the 1970s) and the precursor of the Internet (1980s). But the book is resistant to technophile (tech-savvy) ideology or the belief that technical calculation is superior to human thinking and judgment and can control all our social institutions and concepts such as freedom, efficiency, truth, intelligence, fact, wisdom, history, etc. For Postman, technophiles are unable to understand the effects of their innovations. The history of technological advancements is the history of the relations between technology and culture - with three main periods: the first being tool-using cultures, when techniques like water-mills solved physical problems and served the symbolic power of religion, art and politics; the second is technocracy, during the era of Copernicus, Kepler, Galileo Galilei, Bacon, etc., when techno-scientific rationality (with the telescope, for instance) was in conflict with religion, but society remains under social and religious traditions; finally, the third period is technopoly, emerging in the $20^{\text {th }}$ century with Taylorism, bureaucracy, expertise, and submitting all forms of cultural life to the exclusive domination of technology. Postman here provides convincing examples in medicine of how technology has shaped our vision of the body and of health. Little by little, computers and information technology speed up the change. Information (data) has become the means and the end of human creativity: medical tests, IQ (Intelligence Quotients) tests and opinion polls, are examples of excessive faith and trust in technology and quantification. We can all bring to mind examples of decisions made by computers and algorithms. My aim now is not to approve or reject Postman's position, his rather pessimistic account and his deterministic view of technology. New tools create new environments but do not necessarily exclude other older beliefs, as we can see with the role of religions in today's policies across the world.

The other multidisciplinary approach trying to reconnect technology and culture is mediology, elaborated by Regis Debray, French philosopher and journalist (Debray 1991, 1994, 1997). In studying methods used to store, transmit, pass down and disseminate cultural knowledge, this media philosophy, much more than a simple sociology of mass media, sets out to demonstrate how media (as techno-typical and ethno-cultural vectors of transmission) do not only serve to conserve data, information and knowledge, but are also constitutive: they shape our mind-set, our beliefs, our social organisation. The material act of transmitting between individuals, groups, organisations and societies, is different from "communication",

\footnotetext{
2 Another perspective is worth mentioning here: the social construction of technology (SCOT). See Olohan (2017) for an overview.
} 
monopolised according to Debray by language theoreticians and university programmes or departments. Mediology ("medio" here standing not for medium but for mediation between the production of signs and production of events, Debray, 1994, p. 29) studies the interplay between three interdependent aspects of culture: the symbolic forms (religion, system/doctrine and arts), the collective organisations (such as church, school), and technical systems of communication (to understand, memorise, archive, disseminate cultural knowledge and traces). In other words, information, ideas and cultures do not travel isolated, free of the ground ("sol/hors-sol"), but through media over time and over spaces. The mediation articulates "organised material" (OM), subdivided into the physical courier (OM1), the mode of expression (OM2) and the disposal of circulation (OM3), and "materialised organisation"(M0), also subdivided into three elements: the linguistic code (M01), the framework of the organisation (MO2), and the matrixes of communication (M03). Between messages, mediums and media environment there are feedback loops of causal co-determination. If writing is the OM, then $\mathrm{OM} 1$ is text, $\mathrm{OM} 2$ printing press and $\mathrm{OM} 3$ books. As to the institutional vectors of transmission, we have the national language as M01, academies, libraries, scholarly periodicals, cabinets of reading as $\mathrm{MO2}$, and notion of copyrights, discourse of reception, exchanges in learned societies as M03. The 18 issues of Les Cahiers de Médiologie (1996-2004) give an overview of both the scope and the resources of this interdisciplinary approach: objects as interfaces, such as road, bicycle, car, money, paper, monument/memorial, body (tattoo, body building, face, etc.) and objects as direct correlations between culture and technology, such as war, networks, smartphone, light, performances/shows, museums, music (instruments and records) have all been the topics of many articles. Books, roads, bicycles (think of the new roles of bicycles in our societies now experiencing the climate change) are efficient when they rely on institutions, communities and places of production (schools, post-offices, libraries, etc.). In a way, mediology has some similarity with the inquiries of the Birmingham School of Cultural Studies (1964-2002). For Debray (1991, chapters10-12; 1994, Annexes), the history of mankind has passed through three media spheres, happening one after the other but not cancelling each other out in the infrastructure and in our memory: the logosphere, still dominated by oral culture even if it follows the invention of writing, the graphosphere, from the $15^{\text {th }}$ century with printing to 1968, and the videosphere, with images, photo, video (the audiovisual stage). Today, with the Net, the Web and digital networking, we could add a fourth sphere: the cybersphere or the hypersphere. This cultural structuring of technology in three or four spheres shakes up the traditional history of the arts, media, culture and technology, usually considered as separated from each other.

Now as we have learned from culture and technology, let us return to translation practices both in history and today.

A Snapshot of a Media History of Translation
The set of epistemic and socio-institutional elements of any discipline cannot neglect the impact of the material forms on the production, organisation ${ }^{3}$, circulation and reception of discourse and knowledge. In this section, we draft a very short media history of translation. Practices of writing and reading have changed according to the material forms (wood, stone, the human body, tablet, roll, codex, book and computer) available at a given time for the storage and retrieval of data and information. The physical supports (voice, clay, wax, silk, papyrus, parchment, paper and screen) make a difference to our practices of writing, reading and translating. We know how Luther (mid-16 th century) combined printing and translation

3 Or how knowledge has been sorted out, identified, indexed, compiled, allocated, consulted, and distributed while the information load never stops increasing. See Blair, 2010; D’hulst \& Gambier, 2018. 
and how Google uses the power of computer memory and calculation to develop machine translation. As to reading (Cavallo \& Chartier, 1999; Richter, 1998; Manguel, 1996), it is always a practice embodied in certain gestures, in a given space, in relation to oneself and others (Jousse, 1990, 2008). Through history, reading was collective (somebody reading aloud to others), public (recitatio), as a mode of socialisation (in a group), sotto voce (murmured), suppressa voce (in a very low voice), silent (reading alone), entertaining, as a social marker, etc. Sometimes a mode was almost exclusive; sometimes two or three coexisted. Until the mid- $14^{\text {th }}$ century, the kings and most of the lords in France had somebody else reading manuscripts for them. All those arrangements, rituals, and modes impacted upon the relationship to written texts and were never developed in a strictly linear way.

Cultural history has easily traced the influence of technical tools, for instance in the evolution of printing, but our attention has not yet been drawn to this influence in translation (Cronin, 2003; Littau, 2011). Book historians have opened up the way when describing the logosphere, graphosphere and cybersphere. Today, as in the past, several types of culture in relation to media co-exist: paper and screen, one being, temporarily, in a dominant position in certain spheres of activity (journalism, administration) until a balance between the two is found or paper is completely replaced by computer.

Because of the lack of space and also the lack of systematic knowledge of media history of translation in China, in the Arabic world, etc., I limit the presentation to Europe, admittedly in a too linear way - the goal here being only to emphasise the importance of the materiality of translation in the historiography of Translation Studies. First, we revisit how translating was done before Gutenberg, how the print culture changed the concept of translation and the distribution of knowledge, and then how the move from books to the Web is again changing the working conditions of translators. In each period of time, we consider four aspects: the way of working in translation, the concept of text at the time, the way the dominant medium ${ }^{4}$ was produced and distributed, and the reading mode.

I will not consider here the practice of composing and translating orally and on a scroll in Rome, with Cicero (106-43 BC) for instance, up to the $8^{\text {th }}$ century. However, I do wish to remind the reader that on a scroll (the two wooden cylindrical sticks held in two hands by somebody else), a text is a set of vertical columns displayed horizontally when the scroll is unrolled. It is not without analogy to a computer or tactile tablet where you scroll up and down the document you wish to read. Working with the human voice and with the memory is far from our graphoscentric perspective, including its digital form, in which memorising is a part of the technology and no longer plays a major role in learning and reading.

The European Middle Ages was a culture largely based on a handwritten codex (tablets tied together with a string or a thread, covered by a skin or a piece of wood), mainly from the beginning of the $5^{\text {th }}$ century onwards when translations were made under the patronage of the king, the church or a prince. Codices appeared in the Byzantine Empire, in particular in the 8-9th centuries, and gave rise to what has been called the "Byzantine Iconoclasm". Codices were made by scribes and illustrators and produced for a particular patron, usually its future owner, with a specific audience in mind. This is quite different from book production aiming at a large market but rather similar to an iPad with a lot of pictures. Each codex is a unique artefact; it was a localised undertaking, involving personal relations and collaborative work. The type of work done translating in pairs in the $12^{\text {th }}$ century (one working from Arabic to spoken Romance, the other one from Romance to Latin) was already a kind of collaborative translation.

\footnotetext{
4 Very often, "text" is confused with "book". The medium and the format of a publication are different from a text, even if they impact upon it (Illich, 1991).
}

From Codex to the Printing 
The Gutenberg Parenthesis
When a codex was lost or only available as copies (often textually corrupted over time), the translator had to reconstruct the text by using a variety of sources: surviving fragments held in different locations (codices travelled and were copied), translated parts in different languages or dialects, quotations embedded in other works, etc. The translation could not and cannot be compared to the fragmented, misrepresented, manipulated "original"; it could be a "source" text as a point of departure for the translation but not a standard against which to evaluate the new version (Ellis, 2000).

Codices both derive from the oral tradition (promoting adaptation and free translation) and introduce textual features found in a print culture (promoting a more literal translation strategy) (Tymoczko, 2010, p. 219, 228; Hermans, 1992, 1997). The literal approach was justified in a monastic scriptorial context where assumed faithfulness to the Word of God demanded a word-for-word rendition. Between the variations in the production and circulation of codices and the insistence on remaining as close as possible to the sacred text, we can appreciate the complexity of translating in the Middle Ages. That could explain the diversity of labels for translation: compilatio, ordinatio, and imitatio. In the handwritten tradition, various forms of writing had arisen; composing, annotating, glossing, translating, and copying, with omissions, additions and comments - to the extent that the receiver had a central position in interpreting texts. Besides, when parchments became more common than papyrus and, therefore, the codex less fragile and more capacious than the roll, readers could have easier access to any part of the text - pagination, internal division of the text, index of concepts, synoptic tables, punctuation, notes, and a table of contents transformed the codex little by little, between the $11^{\text {th }}$ and the $14^{\text {th }}$ century (Illich, 1991; Grafton, 2012). Several texts could be then gathered in the same codex and a codex could be held with one hand, enabling the reader to make notes with the other hand (Cavallo, 1999). The monastic habit of reading aloud gave way to new scholastic habits (reading silently and annotating).

What happens with a print culture? The invention of moveable type printing technology 5 in the mid- $15^{\text {th }}$ century in Europe led to new changes in the production, consumption and transmission of texts. ${ }^{6}$ From then on, presses could produce multiple identical copies, ${ }^{7}$ admittedly with unintentional variations in spelling, textual modifications because of the printing process and also pirated and counterfeited editions. Subsequently, text can be considered both as an object (already around 1150) and a printed object (around 1460), with a transition from a murmured reading to silent reading (Illich, 1991). However, and more importantly, there was an increasing demand for reading material (RED, 1996). The vernacular languages (not to be confused with national languages promoted by states between the $16^{\text {th }}$ and $19^{\text {th }}$ century) became languages to be learned. Parts of the Bible were translated into many vernacular languages in a short period of time: in Dutch in 1526, in German in 1530 (in Zurich) and 1534 (by Luther), in Italian in 1532, in French and in English in 1535, in Finnish in 1548. The Luther Bible was reedited, partially or totally, more than 400 times before he died in 1546. In translations, the layout of the originals in Latin shaped the translation strategy. Translation is then not only an inter-lingual process but also an inter-medial transfer, as today with tourist brochures, illus-

\footnotetext{
5 The manufacturing technique of paper was invented in China between 100 years before and 100 years after beginning of the Common Era. The technique was acquired in Japan and Korea around 600 but not before the $12^{\text {th }}$ century in Europe (in competition with parchments made of skins of calf, goat, or lamb).

6 It is important to remember the different phases of expansion of Gutenberg's invention. It was not adopted, for instance, by Istanbul before the $18^{\text {th }}$ century.

7 Printing from the $15^{\text {th }}$ to the $17^{\text {th }}$ century cannot be seen as comparable to that of the industrial revolution of the $19^{\text {th }}$ century (wholesale, mass production), although the readers already no longer selected the types of writing, the illustrations, the binding of the books, etc.
} 
trated books and advertisements, etc. about which many scholars speak of adaptation (and not translation, too frequently considered to be a word-for-word substitution).

In parallel to these changes, ${ }^{8}$ a literate bourgeoisie and a national language emerged, for instance in France. Translations served a new readership (Jouhaud \& Viala, 2002) and a certain ideology. Berman (2012) talked about the twofold origin of the institutionalisation of translation in the country, between the $14^{\text {th }}$ century (with Oresme, tutor of the King Charles V and designer of the learned French within the transfer of knowledge from Latin) and the $16^{\text {th }}$ century (with Amyot, in favour of free adaptation, creating a certain type of prose). Between the Renaissance and the mid-20 $0^{\text {th }}$ century, since the source text can be identified and replicated as such, a new concept of translation and a comparative approach between the source and target texts became established, supporting the concept of equivalence, the translation as a secondary text and the illusion of equal languages (Pym 2004, p. 173-74).

The equivalence paradigm which dominated in translation over the last 500 years is the quest to convey identical meanings, a straightforward transfer of meaning between languages (Torres-Simón, 2019). There are strong assumptions underlying such an approach of an implicit framework of the communication model where a message is transferred from one language to another and the tropes of border and bridge work powerfully. It assumes, for instance, that two languages "do or can express the same values" (Pym, 2009, p. 82). But a word or a concept may connote different meanings in another language or may be absent altogether, so the relationship between the two languages is not necessarily symmetrical. Two words may also refer to the same object, and this would not necessarily convey the intended meaning of the original text. Loyalty to the source text may result in a text that is not easily comprehensible in the target language. Nevertheless, the view of translation as a transparent non-entity usually compels people to stigmatise or criticise a translation because certain words have not been replaced.

The other aspect to be taken into account with the equivalence paradigm is how the so-called equal languages are categorised. Here again, the reflections are limited to Europe. Early in the Middle Ages, intercultural communications were regulated within a certain hierarchical system of languages, with those languages supposed to be close to the word of God, namely Aramaic, Hebrew, Greek and Latin, at the top, followed by vernaculars based on Latin and then by dialects/patois, as shown by polyglot Bible preserved in Salamanca and Antwerp. ${ }^{9}$ The Renaissance was the age of vernaculars, equal in principle. However, at around the same time, the concept of the nation-state began to emerge, with a language as one of its attributes. Translators as mediators begin to be placed into a kind of double bind: their linguistic loyalty contradicted the national borders they were trying to overcome. Their identification is two-way. The association of state, nation, territory, language and culture rejects the continuum between languages and leads to typologies of languages, as if languages could be isolated, counted as apples, separated and without contacts (Sakai, 2009). Dialects, patois and standard forms became connoted, anchored in a certain political and linguistic ideology, like "purism" which excludes any forms of "contamination" or hybridisation, and thus discrete categories are created, such as, to give only a few examples, Serbo-Croatian, Serbian, Croatian (Hlavac, 2015), or the Belgian French, Québécois French, trendy French—variations

\footnotetext{
8 With the polyglot Bible or Biblia Regia printed by Ch. Plantin in 1572 and the printing of Theatrum Orbis Terrarium of A. Ortelius in 1570, the first ever made Atlas with more than 40 editions in the $16^{\text {th }}$ century, we can say that Antwerp was the city where a new vision of the world was elaborated.

9 Today, the hierarchy still remains but inspired by technologies, and not by God: there is a lingua franca for the internationalisation of business and goods, then languages which justify a full localisation, languages which imply a partial localisation and, at the bottom, languages which could require localisation but, because of a lack of means, do not localise at all.
} 
of the same "language" or different "languages". From the $13^{\text {th }}$ century, with Dante Alighieri (De Vulgari Eloquentia), who divided languages between $\mathrm{Si}, \mathrm{Oc}$ and Oil languages, up to the 18-19th centuries, when, within genetic categorisations (William Jones, Franz Bopp) and different typologies, for instance those by the brothers Von Schlegel, languages were defined in order to be adapted to political agendas. Antoine Meillet (1928) has identified two types of language: on the one hand, dominant, written, national languages, and on the other hand, the spoken languages, dialects, popular languages and local languages. In his list, there is a clear hierarchical system between the so-called prestigious languages (Greek, Latin and "civilised languages") and the stigmatised ones, with national languages in an in-between position. It is worth mentioning that Translation Studies remains dependent upon such categorisations although the postcolonial approach calls them into question, and digital technology blurs the clear cut between written and oral modes of language.

In the 19th century, the circulation of texts accelerated. The business and trade of books encouraged the development of secular literature, journals and newspapers. Coffee houses, kiosks, and different street panels rapidly spread news while magazines gathered texts and ads: all of them introduced graphic design, to the degree that in the 1920s some were already criticising the "Americanisation" of our society. The expansion of book production was then boosted again with popular and pulp literature (around 1860) and the launch of paperback books (around 1950), while legal protection (copyrights) of foreign works did not then exist. "Active retranslations" (Pym, 1998, pp. 82-83) became relatively frequent in markets which were more competitive. We are now far from scrolls with words tied together and no punctuation and from codices with illuminated pages.

From then on, the need to be able to read fast and silently was satisfied since printers and typesetters had systematised, though not yet standardised, both layout and spelling. Another reason for this twofold demand in reading could also be, at least in certain societies, that translators had opted for fluency as the dominant strategy in order to suit their audience (Venuti 2018 [1995]).

This section was entitled "The Gutenberg Parenthesis", borrowed from Sauerberg (2009). The metaphor sheds light on the age of print, not so much as a clear cut period but rather as a certain period during which the world was viewed in terms of categories/typologies, the mediation of texts was dominated and contained by the powerful permutation of letters, pages and books, pushing away the era of scribal transmission and oral performance, and then challenged in many ways by digital culture and the orality it embraces (since sound recording with film, radio, TV and, today, the Internet), based on a return of fluidity in communication (cf. McLuhan, 1962, 1964; Ong, 1982).

From the Print Culture to the Digital Culture
Our concepts of text, reading and translating are thus far based on print documents. As they are transformed into digital materials, our assumptions on textuality and readability have begun changing. New demands, new needs are appearing. The textual devices and arrangements are also changing, since the manner of their reception is less and less predictable. All the new textual forms and formats are translated, localised and adapted - moving away from a perception and conceptualisation of translation referring mainly to religious and literary printed texts. The interaction between text, author, reader and translator is deeply changing (Gambier, 2015).

There are differences between a text by Cicero and Virgil (to be read aloud during a public event) and a text by Proust (to be read silently), between a literary text and annual reports, instructive texts (read here and there) even if they are all physically limited and semantically open, while hypertexts are both physically and semantically open: there is no single relationship between an online text and the reading context, the reader's expectations. A digital page 
is a set of commands, making possible an infinite number of (re)combinations and proposing a fragmentary text. Besides, one reads an electronic text additionally referring to an interview on You Tube, a public lecture or a map, as one watches a film whilst additionally watching a video-clip, a trailer, rushes, etc. Two users can open a website with the same webpage but can end their navigation after opening different links. A printed text does not activate the brain or the memory in the same ways as a digital text. Three decades of the Internet and the Web, including audio-visual products, have transformed a concept which was dominant for thousands of years (Gambier, 2016). From now on, "texts" are fluid with other "texts" and other systems of signs (fixed or moving images, graphs, colours, fonts, sounds, etc.). A "text" has become poly-semiotic or multimodal (with multiple modes of sense-making) and exists in a permanent intertextual relationship with other "texts" (Kress and van Leeuwen, 1996, 2001; Tuominen et al., 2018; Boria et al., 2020). While printed texts could always be dated, allocated to an author or editor or printer, digital/audio-visual texts can be constantly updated and offered in different versions (Pym, 2004). There is a moving "start text" but no strict source text to refer exclusively to (Pym, 2013). Moreover, the translation act is now visible on the computer screen: readers (including other translators) can partake in the process and have the possibility to compare multiple translated versions, rather than just compare the source and target texts.

In our digital culture today, fluency aiming at optimal readability according to linguistic, rhetoric and stylistic criteria is being replaced by accessibility and usability; the focus is then less on the text than on the receivers (readers, viewers and users) - changes anticipated in a way by the functionalist framework in Translation Studies - moving away from a contrastive approach towards a target approach. Accessibility is a key word for instance in media and audio-visual translation (AVT), not only as a legal and technical issue related to people with disabilities (vision impairment, deafness, cognitive difficulties, people in wheelchairs, etc.) but as a concept which encompasses the digital divide, access to the Internet, etc. It shakes up the dominant way of assessing the quality of a translation. It covers a variety of features: if we consider AVT, it includes acceptability, legibility, readability (for subtitles), synchronicity (for dubbing, voice-over and free commentary), and relevance in terms of what information is to be conveyed, deleted, added, or clarified. Usability aims at optimising the user-friendliness of AVT, software, web sites and other applications. In other words, there are measures and tests able to confirm how to achieve a goal safely, effectively and efficiently when users in a given context perform a task with a product, a machine, device or computer programme, which should provide optimal conditions for the performance. Moreover, today, an online text (but not necessarily a book in an electronic format which retains its forms derived from the print culture) can have a new configuration thanks to its users: they are invited to add their own words and images to co-construct the meaning and become prosumers (producers and consumers). Such user-centred participation, with prosumers, fans and volunteers, generates new genres: wikisites, blogs, tweets, websites, etc.

The traditional division of labour between the production of a text, film or piece of music and their distribution is blurred in the digital world. The ongoing changes in translation practice are not confined to professional translation and localisation activities. The recurring distinctions made in reference to translation often focus on the qualifications of the participants, opposing professionals to natural translators, amateurs, or non-professionals (Antonini, 2011; Antonini et al., 2017). Myriad types of users have in fact emerged. Technologies offer new opportunities and niches that did not exist before, in addition to the new problems they raise. One prominent example is the use of machine translation by general users everywhere. Programmes available on the Web for free allow users to upload content and to get the gist 
of the text. Human intervention can be limited, even non-existent. A second kind of general user ${ }^{10}$ includes those who may have no professional training but who manage or are fluent in languages other than their mother tongue. They carry out such activities as fan translation, fan subbing, fan dubbing, and scan-trans on deliberately chosen mangas, animated films, and video games. These fans are not translation professionals - hence, they transgress certain conventions and respected norms of the profession. A third type of user-translator participates in projects that are less "fan"-motivated but clearly project-centred. Often referred to as participatory or collective translation (with implied crowdsourcing), they translate and/or localise software, websites, articles, reports, literary texts and interviews. For this collective, unpaid effort, volunteer and anonymous (or sometimes not) participants rely on their linguistic competence and translate and revise whatever and whenever they feel motivated to do so, until the entire project is complete. They can translate thanks to such tools as Traduwiki, Wikitranslate and Google Translate (Jiménez-Crespo, 2017; McDonough-Dolmaya \& Sánchez-Ramos, 2019). Social media or socio-digital networks (Facebook, Twitter, Linkedln, etc.) take advantage of this collective will to translate in order to become more accessible to sectors of the population they may never have envisioned originally. Finally, there continues to be considerable collaborative translation work (as a team) carried out by a mix of professional working and professionally trained (but not necessarily working) translators. They share resources, can work on the same document or content from diverse locations, and share activities of translation, research, terminology management, revision and proofreading. One may bid for translation jobs or projects for which qualifications and requirements can be posted (Proz and Translator's Café are two examples). The collaboration in translating ${ }^{11}$ also changes the process. See, for instance, the new translation of the Bible into French (2001), made by specialists in exegesis and writers, or the new translation of Joyce's Ulysses (2004) by a group of eight translators, or any project of localisation in which agents are either in face-to-face contact or are so in cyberspace (Pym, 2004, pp. 17172). Volunteer networked translation can also be carried out by professionals, for example, through networks such as Babel, Translators without Borders, the Rosetta Foundation, etc. (Gambier, 2007). These activist or altruist translators work for a specific cause, and respond to the needs expressed by NGOs and other associations.

Multimodal text, new ways of reading, changing parameters of quality (accessibility, etc.), a new division of labour implying new types of production with different types of agents all challenge a long tradition and a certain ideology which claims that a translation is always an individual act, focused on a written text, and considers the translator to be a substitute for the author. These new practices might disqualify, or de-professionalise, full-time translators who are trained and experienced with the basis of binary oppositions (source text / target text, author / translator, literal / free translation, faithful translation / adaptation, denotative / connotative meaning, etc.). The current changes do not exclude the fact that some tools seem to resonate regressively, implying a return to the old concept of a translation that is word-based and a formal, mechanical, countable transfer. The line-by-line translations of European Union directives, produced with the constrained aid of translation memories,

\footnotetext{
10 The terminology used in English for amateur translation is redundant and vague: community / crowdsourcing / collaborative / citizen / paraprofessional / user-generated / volunteer translations, in addition to the 3CT proposed by Common Sense Advisory, to wit: community, crowdsourced and collaborative translation. See also Hebenstreit, 2019. 11 Collaborative translation is also ambiguous (Cordingley \& Frigau Manning, 2017; Monti \& Schnyder, 2018): it can be understood as the cooperation between two scholars translating the same text, the work between a writer and his/her multiple translators, the process of target text coproduction or the team work of several translators. Some scholars consider the legend of the translation of the Septuagint (mid- $3^{\text {rd }}$ century BCE) as an example of collaborative translation, but the 72 Jewish translators made their own translations at the same time, separately, although with identical results.
} 
the practice of subtitling in direct, or the subtitles of fans, all tend to stick to the source and become verbatim. Again, changes are never a quiet linear stream. The tension between the individualistic approach and the collaborative approach is not new: the former has been dominant in Western Europe from the Renaissance, that is, the mid- $14^{\text {th }}-$ mid- $16^{\text {th }}$ centuries (Bistué, 2013), with a peak in the Romantic period (19 $9^{\text {th }}$ century), to the end of the $20^{\text {th }}$ century. The latter seems to be spreading today through the use of translation memory systems, cloud translation, fansubbing and the use of different types of communities on the Web.

To sum up, from Cicero to today, translations have always been marked by the technical environment, even though we have paid little attention to it until now. ${ }^{12}$ Their existence is inseparable from the material medium which embodies them. However, there is no clearcut correspondence between a medium and a given period of time: different media co-exist in a culture at a certain moment. The linear presentation of some examples should not fool anyone: time and space are not monolithic. The transition from analogue to digital, from the linear and continuous verbal sequence to hypertext, from a finalised and stable text to a volatile, short-lived document which can be updated at any moment is never direct. The change of tools and media has a complex repercussion on the global system - on institutions, on social life, on political organisation, and on legal matters. Thus, it is important to analyse the technological offer within a cultural frame. At the moment, the changes are so rapid, and sometimes controversial, that it is difficult to follow and understand what is happening. Nonetheless, the transition from printing to digitisation explains (to a considerable extent?) the ambiguities or even the contradictions of Translation Studies: indeed, the concept of text, the relationship between oral and written codes, the modes of reading, and our hesitation sometimes to use the word "translation" combine to force us to rethink our technical approaches and our conceptualisations inherited from the technical paradigm of the printed book, and not only copyright infringement.

In the title of this paper, we have "renewing", and several times we have insisted that the digital culture could be a kind of return to the pre-print time - on a roll, a text is unrolled laterally, read aloud; on a screen, we navigate between webpages. In both cases, the text is hardly accessible at once, supposed to be the opposite of a printed text, even a long text, enclosed and bound by a cover. In a codex, a text is illuminated; on a screen, it is multimodal, with a complex interplay between letters, images, and sounds. But what does the prefix re- mean here? Is it a way back, as if history was a cyclic repetition of facts or data? The digital text is definitely not the simple reproduction of a roll or a codex. Is it a revision of or a reversion to what has been done earlier, as if history was a recycling process? But the digital text is not restoring (with some technical adaptations) the media of the $5-16^{\text {th }}$ centuries. The polysemous prefix re-introduces different temporalities: renewing is coming after, again, against, back to previous moves. When referring to the Gutenberg parenthesis, we do not mean an interruption in a linear process, the dominance of 500 years of print being challenged by orality, by fluidity in communication, as if there were a clear beginning and a clear end at a single point of time. There was also orality during the parenthesis - a written play was performed on the stage, a poem could be sung, etc. - and a printed text was never locked in a final, stable form: there were variations in a text between editions. Text is maybe today more mobile, less stable. Nevertheless, we are not returning to a preliterate society: we are perhaps more

\footnotetext{
12 The same caution applies to interpreting: seen as exclusively an oral performance for a long time, interpreting has been under pressure from technology for at least the last 40 years (not to mention the birth of the simultaneous mode) from telephone to speech recognition systems, from the tools available online to virtual reality (Berber, 2010).
}

\section{History as a Spiral}


A Transdisciplinary Perspective than ever writing, communicating in a written form through the Net, the social media, text messaging on a phone. Again, considering history as a set of clear-cut periods is misleading: it is not either/or, before/after. One form of media does not replace another: printed texts are competitive with the electronic format; TV has not removed reading; the Internet mixes oral and written codes. An innovation cannot be analysed in absolute terms but in relation to and in continuity with what is existing.

The historical trajectory can be considered, in a metaphor, as just like a spiral: outgoing but not in a straight way, and constantly turning, but not in a circle. The spiral breaks the straight line, escapes the repetitive circle, goes beyond the routines. Evolutionary, never closed, the spiral comes and goes from inside to outside. It brings together and disseminates.

Transformations, whenever they happen, demand a transversal approach. As contemporaneous examples, we could mention climate change, sustainable development, cognitive sciences, artificial intelligence, public health care, bio-ethics, gerontology, human-machine interactions, etc. To understand the past of translation, as a type of transfer within and between societies, we realise that we need to connect book history, media history, cultural studies, the history of knowledge (including the genesis of encyclopaedias and the techniques of classification), the history of education (from the organisation into a hierarchy of the disciplines, through the birth of universities to electronic resources) to the history of translation, the historiography of Translation Studies. Obviously, the rapid changes in technology today open new priorities, new specialisations, new communications which blur quite a number of borders (always unstable and to be defined). In such a perspective, do we have to maintain separated Translation Studies, Adaptations Studies, Intercultural Studies, Transfer Studies, Media Studies, Knowledge Management, Internet Studies, Web Science, and Globalisation Studies, just to name a few research domains? This does not mean that Translation Studies should or would swallow up neighbouring disciplines such as literary studies, linguistics, ethnology, sociology, psychology, etc. (Gambier \& van Doorslaer, 2016). All of them acknowledge the complexity of communications and behaviours and deal with them but, truly, they still tend to ignore translation, as if information, data, knowledge and documents could be delivered in seconds around the globe in spite of the language diversity, without translations.

Wherever we search, whatever means we use, to give sense and memory to what has never been and is not easily acknowledged is a permanent challenge. After our short overview of the impact of certain media on translation, we can conclude that technological devices and equipment themselves can be understood if we ask questions of their values, their relevance, and their impact on our behaviours, if, in other words, we integrate technology within our culture, and not as something out of cultural and socio-institutional life.

\section{References}

1 Antonini, R. (2011). Natural Translator and Interpreter. In Gambier, Y., \& Van Doorslaer, L. (Eds.), Handbook of Translation Studies, (vol. 2), 102104. Amsterdam: John Benjamins. https://doi. org/10.1075/hts.2.nat1

2 Antonini, R., Cerillo, L., Rossato, L., \& Torresi, I. (Eds.). (2017). Non-professional Interpreting and Translation. Amsterdam: John Benjamins. https://doi.org/10.1075/btl.129
3 Berber, D. (2010). Information and communication technologies in conference interpreting. A survey of their usage in professional and educational settings. Saarbrücken: LAP Lambert Academic Publishing.

4 Berman, A. (2012). Jacques Amyot, traducteur français. Essai sur les origines de la traduction en France. Paris: Belin. 
5 Bistué, B. (2013). Collaborative translation and multi-version texts in early modern Europe. London: Routledge.

6 Blair, A. (2010). Too much to know: Managing scholarly information before the Modern Age. New Heaven, Connecticut: Yale UP.

7 Boria M., Carreres, A., Noriega-Sánchez, M., \& Tomalin M. (Eds.). (2020). Translation and Multimodality. London: Routledge. https://doi. org/10.4324/9780429341557

8 Brügger, N., Goggin, G., Milligan, I., \& Schafer, V. (Eds.). 2018. Internet Histories. London: Routledge. https://doi.org/10.4324/9780203703502

9 Brügger, N., \& Milligan, I. (Eds.). (2019). The Sage Handbook of Web History. London: Sage. https:// doi.org/10.4135/9781526470546

10 Cavallo, G. (1999). Between volumen and codex: Reading in the Roman world. In Cavallo, G., \& Chartier, R. (Eds.), 64-89.

11 Cavallo, G., \& Chartier, R. (Eds.). (1999). A history of reading in the West. Cambridge: Polity Press.

12 Cordingley, A., \& Manning, C. F. (Eds.). (2017). Collaborative translation: From Renaissance to the Digital Age. London: Bloomsbury.

13 Cronin, M. (2003). The Empire talks back. Orality, heteronomy and the cultural turn in interpreting studies. In Tymoczko, M., \& Gentzler, E. (Eds.) Translation and Power, 45-62. Amherst, MA: University of Massachusetts Press.

14 Debray, R. (1991). Cours de médiologie générale. Paris: Gallimard.

15 Debray, R. (1994). Manifestes médiologiques. Paris: Gallimard.

16 Debray, R. (1997). Transmettre. Paris: Le Seuil.

17 D'hulst, L., \& Gambier, Y. (Eds.). (2018). A History of Modern Translation Knowledge. Amsterdam: John Benjamins. https://doi.org/10.1075/btl.142

18 Gambier, Y. (2007). Réseaux de traducteurs/interprètes bénévoles. Meta: Journal des traducteurs/Meta: Translators' Journal, 52 (4), 658-672. https://doi.org/10.7202/017691ar

19 Gambier, Y. (2015). An obsession: .com. Between the rocky shores of myth and the new balance of powers. Kalbu Studijos/Studies about Languages 27, 5-19. https://doi.org/10.5755/j01. sal.0.27.13739

20 Gambier, Y. (2016). Traduction et texte: vers un nouveau double paradigme. Signata. Annales des
sémiotiques/Annals of Semiotics, (7), (1):175-197. https://doi.org/10.4000/signata.1195

21 Goggin, G., \& McLelland, M. (Eds.). (2017). The Routledge Companion to Global Internet Histories. London: Routledge. https://doi. org/10.4324/9781315748962

22 Grafton, A. (2012). La page, de l'Antiquité à l'ère numérique. Histoire, usages, esthétiques. Paris: Musée du Louvre et éd. Hazan. Conferences in Paris, 11-25 June 2012.

23 Griep, H. J. (2005). Geschichte des Lenses: von den Anfangen bis Gutenberg. Darmstadt Primus Verlag.

24 Hammond, M. (2005). The Reading Experience Data Base 1450-1945. Retrieved from http:// www.open.ac.uk/Arts/RED/index.html.

25 Hebenstreit, G. (2019). Coming to terms with social translation: A terminological approach. Translation Studies 12 (2), 139-155. https://doi.or g/10.1080/14781700.2019.1681290

26 Hermans, T. (1992). Renaissance translation between literalism and imitation. In Kittel, H. (Ed.), Geschichte, System, Literarische Übersetzung. Histories, systems, literary translations, 95-116. Berlin: Erich Schmidt.

27 Hermans, T. (1997). The task of the translator in the European Renaissance. Explorations in a discursive field. In Bassnett, S. (Ed.), Translating Literature, 14-40. Cambridge: D. S. Brewer.

28 Hlavac, J. (2015). Pre- and post- conflict language designations and language policies. Target 27 (2): 238-72. https://doi.org/10.1075/target.27.2.04hla

29 Illich, I. (1991). Du lisible au visible : La naissance du texte. Commentaire du Didascalicon de Hughes de Saint Victor (12ème s.). Paris: Éd. Du Cerf.

30 Jiménez-Crespo, M. (2017). Crowdsourcing and Online Collaborative Translations. Amsterdam: John Benjamins. https://doi.org/10.1075/btl.131

31 Jouhaud, C., \& Viala, A. (Eds.). 2002. De la publication. Entre Renaissance et Lumières. Paris: Fayard.

32 Jousse, M. (1990). The oral style. New York/London: Garland Publishing.

33 Jousse, M. (2008). L'anthropologie du geste. Paris: Gallimard. 
34 Kress, G., \& Van Leeuwen, T. (1996). Reading Images. The Grammar of Visual Design. London: Routledge.

35 Kress, G., \& Van Leeuwen, T. (2001). Multimodal Discourse: The Modes and Media of Contemporary Communications. London: Arnold.

36 Leonhard, G. (2016). Technology vs Humanity: The Coming Clash between Man and Machine. London: Fast Future Publishing. https://doi. org/10.15358/9783800655342-227

37 Littau, K. (2011). First steps towards a media history of translation. Translation Studies 4 (3): 261-81. https://doi.org/10.1080/14781700.20 11.589651

38 Manguel, A. (1996). A history of reading. London: Harper Collins.

39 McDonough Dolmaya, J., \& del Mar Sánchez Ramos, M. (Eds.). (2019). Characterizing online social translation. Translation Studies 12 (2), 129271. https://doi.org/10.1080/14781700.2019.16 97736

40 McLuhan, M. (1962). The Gutenberg Galaxy. The Making of Typographic Man. Toronto: Toronto UP.

41 McLuhan, M. (1964). Understanding Media: The Extensions of Man. New York: McGraw Hill.

42 Meillet, A. (1928 [1918]). Les langues dans l'Europe nouvelle. Paris: Payot.

43 Monti, E., \& Schnyder, P. (Eds.). (2018). Traduire à plusieurs. Collaborative translation. Paris: Orizons.

44 Morozov, E. (2013). To save everything, click here. New York: Public Affairs.

45 Olohan, M. (2017). Technology, Translation and Society. A constructivist critical theory approach. Target. International Journal of Translation Studies 29 (2), 264-283. https://doi.org/10.1075/target.29.2.04olo

46 Ong, W. (1982). Orality and Literacy: The Technologization of the World. London/New York: Methuen. https://doi.org/10.4324/9780203328064

47 Postman, N. (1992). Technopoly: The Surrender of Culture to Technology. New York: Vintage Books.

48 Pym, A. (1998). Method in Translation History. Manchester: St. Jerome.
49 Pym, A. (2004). The Moving Text. Localization, Translation, and Distribution. Amsterdam: John Benjamins. https://doi.org/10.1075/btl.49

50 Pym, A. (2009). Natural and directional equivalence in theories of translation. In Gambier, Y., \& Van Doorslaer L. (Eds.), The Metalanguage of Translation, 81-104. Amsterdam: John Benjamins. https://doi.org/10.1075/bct.20.06pym

51 Pym, A. (2013). Translation Skill-Sets in a Machine-Translation Age. Meta: Journal des traducteurs/Meta: Translators' Journal 58 (3), 487-503. https://doi.org/10.7202/1025047ar

52 Richter, N. (1998). Cinq siècles de lecture populaire. La formation du système de lecture français de la Renaissance à nos jours. Paris: Société d'histoire de la lecture.

53 Roger, E. (2000). The middle ages. In France, P. (Ed.), The Oxford guide to literature in English translation, 39-45. Oxford: Oxford University Press.

54 Sakai, N. (2009). How do we count a language? Translation and discontinuity. Translation Studies 2(1): 71-88. https://doi. org/10.1080/14781700802496266

55 Sauerberg, L. O. (2009). The Gutenberg parenthesis. Print, book and cognition, Orbis Litterarum 64 (2), 79-80. https://doi.org/10.1111/j.16000730.2009.00962.x

56 Taylor, A. (2014). The People's Platform: Taking Back Power and Culture in the Digital Age. London: Metropolitan Books.

57 Torres-Simón, E. (2019). The concept of translation in Wikipedia. Translation Studies 12 (3), 273287. https://doi.org/10.1080/14781700.2018.15 34605

58 Tuominen, T., Jiménez Hurtado, C., \& Ketola, A. (Eds.). (2018). Methods for the Study of Multimodality in Translation, Linguistica Antverpiensia 17.

59 Turkle, S. (2011). Alone Together. Why We Expect More from Technology and Less from Each Other. New York: Basic Books.

60 Tymoczko, M. (2010). Ideology and position of the translator: In what sense is a translator in-between? In Mona, B. (Ed.), Critical Readings in Translation Studies, 213-28. London: Routledge.

61 Venuti, L. (2018). The Translators' Invisibility. London: Routledge. https://doi. org/10.4324/9781315098746-1 
Yves Gambier. Vertimo kaita ir tęstinumas. Komunikacijos atnaujinimas globalizuotame pasaulyje

Iš pirmo žvilgsnio gali atrodyti, kad technologijos greitai keičia vertimo darbų eigą. Kaip ir daugeliui kitu sričiu skaitmeninès technologijos daro itaką verteju gyvenimui. Technologijos yra taip plačiai paplitusios, kad vargu ar imanoma ivertinti ju sukeltas pasekmes ir paskatintas metamorfozes. Kita vertus, mus taip žavi ịvairūs techniniai prietaisai, kad juos naudodami pamirštame praeiti, o kartais net ją sumenkiname. Nepaisant to, svarbu prisiminti, jog technologijos ir žiniasklaida visada vaidino svarbų vaidmeni mūsų kultūrų evoliucijoje. Žvelgdami i i istoriją, galime pastebèti, kad kai kurios šiuo metu populiarios vertimo praktikos yra laikomos naujomis, nors iš tikruju nèra tokios naujos.

Multimodalinių tekstų, apie kuriuos šiandien kalbame gan dažnai, naudojimas gali būti analogiškas praeityje minimiems tekstų kūrimo ir skaitymo procesams. Galbūt perejjimas nuo logocentrinès prie intersemiotinès ir intermedialinès kultūros užbaigia ribotą istorijos laikotarpi, kuriame vyravo spausdinti leidiniai. „Gutenbergo skliaustu“ eros pabaiga nereiškia, kad vèl turime susidurti su tais pačiais artefaktais kaip XV amžiuje. Remiantis esama literatūra, šiame straipsnyje per istorinę perspektyvą kvestionuojamos ribos tarp vertimo praktikos, žiniasklaidos ir kitų disciplinų.

\section{Yves Gambier}

Dr, emeritus professor, University of Turku, Finland

Research interests

Audiovisual translation, multimodality, discourse analysis, training of translators, terminology

\section{Address}

Piispankatu 11 I 36 - 20500 Turku, Finland

\section{E-mail}

yves.gambier@utu.fi 